\title{
LONG-TERM JOB INSECURITY, JOB SATISFACTION AND ORGANISATIONAL ATTITUDES: TEST OF WARR'S CURVILINEAR HYPOTHESIS
}

\author{
HANS DE WITTE \\ Hans.Dewitte@psy.kuleuven.be \\ Research Center on Stress, Health and Well-Being \\ Department of Psychology \\ Katholieke Universiteit Leuven \\ Belgium
}

\begin{abstract}
Research suggests that job insecurity is an important work stressor, negatively affecting well-being and organisational attitudes and behaviours. This article concentrates on two often ignored issues in this field. First, the consequences of long-term job insecurity regarding job satisfaction, the evaluation of management and organisational attitudes are analysed. Secondly, Warr's assumption of curvilinear associations between job insecurity and well-being is tested, and extended to the evaluation of management and organisational attitudes. The hypotheses are tested with data of 769 employees from various branches of a large European multinational company. In total, 15 reliable scales were used to test the hypotheses. The results show that $48,2 \%$ of the interviewees had worries about their long-term job security. Separate analyses of variance showed that long-term job insecurity was associated with two thirds of the scales. Long-term job insecurity was associated with lower job satisfaction, lower organisational attitudes and a lower evaluation of supervisors and management. Warr's assumption of curvilinear associations with job insecurity was not corroborated, however. Suggestions for practice and for future research are discussed.
\end{abstract}

\section{OPSOMMING}

Navorsing stel voor dat werksonsekerheid 'n belangrike werk stressor is en dat dit welstand, organisasie gesindhede en gedrag negetief affekteer. Die artikel konsentreer op twee onderwerpe in hierdie veld wat gereeld geignoreer word. Eerstens word die gevolge van langtermyn werksonsekerheid met betrekking tot werkstevredenheid, die evaluering van bestuur en organisasiegesindhede geanaliseer. Tweedens, is Warr se aanames van kromlynige verhoudings tussen werksonsekerheid en welstand getoets, en uitgebrei tot die evaluasie van bestuur en organisasiegesindhede. Die hipotese is getoets met data van 769 werknemers van verskeie takke van 'n groot Europese multinasionale maatskappy. Daar is in totaal 15 betroubare skale gebruik om die hipotese te toets. Die resultate dui aan dat $48,2 \%$ van die persone angstig was oor hulle lang-termyn werksekuriteit. Afsonderlike analise van variansies toon dat langtermyn werkonsekerheid geassosiëer was met twee derdes van die skale. Lang-termyn werkonsekerheid was geassosiëer met laer van werkstevredenheid, laer organisasie gesindhede en 'n laer evaluasie van toesighouers en bestuur. Warr se aannames van kromlynige verhoudings met werksonsekerheid was nie bevestig nie. Voorstelle vir toekomstige navorsing word ook bespreek.

The last few decades have been marked by important organisational changes. In Europe and the United States, but also in South Africa, increasing international competition brought about large-scale restructuring, mergers, downsizing and plant closings, in an attempt to reduce costs and to increase organisational efficiency (Hitt, Keats, Harback \& Nixon, 1994). These interventions are usually accompanied by massive staff dismissals (Kozlowski, Chao, Smith \& Hedlung, 1993). Simultaneously, in order to meet the need for more (internal) flexibility, the number of temporary employees shows a significant increase (Purcell \& Purcell, 1998). These developments probably affected employees' job security, resulting in heightened feelings of job insecurity in many countries (OECD, 1997).

Job insecurity refers to concern about the continued existence of jobs (Hartley, Jacobson, Klandermans \& van Vuuren, 1991; Sverke \& Hellgren, 2002). It involves employees' subjective perception of their future: the employees concerned are uncertain whether they will keep their job or eventually lose it. Definitions also refer to feelings of helplessness in retaining desired job continuity (Greenhalgh \& Rosenblatt, 1984), and to the involuntary nature of job insecurity (Sverke \& Hellgren, 2002).

An extensive research tradition originated on the psychological consequences of job insecurity (see e.g. Hartley et al., 1991; Klandermans \& Van Vuuren, 1999; Sverke, Hellgren, Näswall, Chirumbolo, De Witte \& Goslinga, 2004).

Requests for copies should be addressed to: H De Witte,

Hans.DeWitte@psy.kuleuven.be
Research documented the detrimental consequences of job insecurity for the health and well-being of individual employees (for an overview, see De Witte, 1999; Nolan, Wichert \& Burchell, 2000; Sverke \& Hellgren, 2002). Job insecurity is consistently associated with lower levels of relevant job attitudes, such as job satisfaction and job involvement (for meta-analytic results, see Sverke, Hellgren \& Näswall, 2002). Job insecurity is also associated with higher levels of burnout (Dekker \& Schaufeli, 1995; Landsbergis, 1988), anxiety and depression (Orpen, 1993; Roskies \& LouisGuerin, 1990) and psychosomatic complaints (Van Vuuren, Klandermans, Jacobson \& Hartley, 1991). Longitudinal research confirms the causal impact of job insecurity on these indicators (Burchell, 1994; Heaney, Israel \& House, 1994; Iversen \& Sabroe, 1988; Van Vuuren, 1990).

Job insecurity also influences various organisational attitudes and behaviours. As a consequence, job insecurity also affects the organisation (see e.g. De Witte, 2005). The perception of job insecurity is frequently linked to reduced organisational commitment (Davy, Kinicki \& Scheck, 1997; Lord \& Hartley, 1998), mistrust in management (Ashford, Lee \& Bobko, 1989) and intentions to leave the company ('turnover intentions', e.g. Barling \& Kelloway, 1996; Davy et al., 1997). These effects of job insecurity threaten the organisation's survival (Greenhalgh \& Rosenblatt, 1984), since they reduce the work efforts of the employees concerned. Job insecurity is also associated with decreased safety motivation and compliance, increasing the risks of workplace injuries and accidents (Probst \& Brubaker, 2001). 
Here too, meta-analytic results suggest that job insecurity has detrimental consequences for organisational attitudes and behavioural intentions (Sverke et al., 2002).

The consequences of job insecurity for the well-being of individuals and for their job and organisational attitudes, have been studied extensively. This, however, does not mean that there is no need for further research on this issue. First of all, it seems worthwhile to replicate research on the consequences of job insecurity in a large number of countries (e.g. South Africa), in order to check whether the findings of previous research can be generalized across the world (cf. Sverke et al., 2004). Furthermore, various issues still remain unsolved. In this article, two such issues will be addressed. One relates to the measurement of specific facets of job insecurity, and the other to the need to test theories in the context of job insecurity research.

\section{Consequences of long-term job insecurity}

Various measurements have been developed in order to assess feelings of job insecurity. The measurement used, depends upon the definition of job insecurity. Some prefer to focus on a global concept, e.g. the overall concern about the continued existence of the actual job in the future (e.g. Sverke et al., 2004). Others choose to analyse a more complex, multidimensional concept (e.g. Ashford et al., 1989), in which they distinguish various aspects of job insecurity. Another distinction relates to quantitative versus qualitative job insecurity (Hellgren, Sverke \& Isaksson, 1999). Quantitative job insecurity refers to the retention (or loss) of the job itself: Workers do not know whether they will be able to keep the job or become unemployed. Qualitative job insecurity refers to uncertainty about the potential loss of (valued) aspects of the job, such as wages, working hours, colleagues or responsibility in the job. The distinctions between global versus multidimensional measures, and between quantitative versus qualitative measurements are independent of each other. Global measures can be quantitative or qualitative. The same applies to multidimensional measures.

In this article, the focus will be on global measures of quantitative job insecurity. In the literature, various measures of this kind have been proposed. One could focus on affective versus cognitive job insecurity (e.g. Borg \& Elizur, 1992), or on the strength or severity of the threat imposed by job insecurity (e.g. Greenhalgh \& Rosenblatt, 1984; Hartley et al., 1991). In devising scales, however, researchers seem to have ignored the issue of the time span. The use of the time frame is unclear or inconsistent in most scales. Some authors do not specify a time frame, but simply ask their respondents to "look at the future" (e.g. Ashford et al., 1989; Kinnunen, Mauno, Nätti \& Happonen, 2000). Others mix various time frames in the same scale, which makes it difficult to assess the impact of a specific time span (e.g. Davy et al., 1997; Lim, 1996). When the time span is specified, most global measures seem to focus on imminent job loss (Roskies \& Louis-Guerin, 1990; Sverke \& Hellgren, 2002). Many researchers only use one item to measure this concept, typically phrased as "How do you assess the probability of losing your job in the near future?" (e.g. De Witte, 1999; Mak \& Mueller, 2000; Mohr, 2000; Roskies, LouisGeurin \& Fournier, 1993).

Surprisingly little research has focused on long-term job insecurity and its consequences. It is, however, likely that workers experience more job insecurity in the long-term compared to the short-term. The perception that one could become unemployed in the near future is probably determined by the actual economic situation of the local company in which one works. The perception of job (in)security in the long-term is probably influenced by additional variables, like the possibilities to find another (similar) job and the general economic climate of the broader environment in which ones lives (including e.g. the number of plant closures (or retrenchments) and the level of unemployment in the region and country during the last few years). As a consequence, long-term job insecurity might affect a larger number of employees than short-term unemployment, as shown by Roskies and Louis-Guerin (1990). In their research, about $4 \%$ of the respondents stated that they expected termination in the short-term, whereas no less than $42.9 \%$ were concerned about long-term insecurity (e.g. the inability to keep the present job until normal retirement). Roskies and Louis-Geurin (1990) seem to be the only researchers who compared the consequences of both longterm and short-term job insecurity. Their results suggest that both aspects are associated with lower physical health and mental well-being, and with lower levels of work effort and career satisfaction.

Since little research has focussed on the consequences of long-term job insecurity, this issue will be at the core of this study. Research shows that job insecurity has detrimental effects on job and organisational attitudes. Because these effects are well documented in the literature, one can assume that they will also apply to long-term job insecurity. The first hypothesis of this study thus reads: long-term job insecurity will be associated with lower levels of job satisfaction and with less positive attitudes towards the organisation. In this article, a secondary analysis of previously collected data will be performed. The dataset contained a large number of relevant scales. This enables the formulation of three groups of hypotheses. The assumption is made that long-term job insecurity will be associated with lower job satisfaction (hypothesis 1a) and lower organisational commitment and related attitudes (hypothesis $1 \mathrm{~b}$ ). The dataset also contained scales regarding the employees' evaluation of the management of the company in which they work. This aspect lies in between the two previous aspects: It relates to satisfaction (first aspect) with the management of the organisation (second aspect). This leads to the assumption that long-term job insecurity is also associated with a less positive evaluation of the management of the company (hypothesis 1c).

\section{Warr's assumption of non-linear associations with} job insecurity

Research on the consequences of job insecurity is largely descriptive. Scholars mostly analyse whether a given measurement of job insecurity is related to a specific outcome variable. The belief that such an association can be expected, is often based on the assumption that job insecurity acts as a work stressor. Most scholars thus use job stress theory, even though they rarely specify its exact nature.

The relative lack of theory in job insecurity research could become problematic in the long run. After some years, most associations will have been explored. As a consequence, scientific knowledge will not increase anymore, and the topic could disappear from the research agenda, despite its relevance for society. The use of theory will not only enrich job insecurity research. The opposite is equally true: Job insecurity research is an interesting field for testing (and further developing) theory as well. In this contribution, an attempt will be made to test one aspect of a recent theory in work psychology: the 'vitamin model' of Peter Warr (Warr, 1987 and 1994).

The 'vitamin model' is a broad and comprehensive theoretical framework in which nine environmental features ('vitamins') are identified which impact on mental health (Warr, 1987 and 1994). Applied to the work context, the model postulates that aspects such as the availability of money, opportunity for control and variety, increase affective wellbeing. One of these environmental features is called 'environmental clarity'. According to Warr (1987 and 1994), this variable covers three categories: feedback about tasks, 
role ambiguity and job insecurity. In this article, the focus is on job insecurity, as part of the broader dimension of 'environmental clarity'. Typical for the theory of Warr is that he postulates non-linear associations between the various environment features and affective well-being. Regarding environmental clarity, Warr's assumption is that too little as well as too much clarity is harmful. The association of this variable with affective well-being thus has a curvilinear shape. Applied to job insecurity, this hypothesis reads as follows: moderate levels of job insecurity will be associated with higher levels of job satisfaction, whereas high as well as low levels of job insecurity will be associated with lower levels of job satisfaction (hypothesis 2a). The view that a high level of job insecurity is harmful, is consistent with most job insecurity research (e.g. Sverke \& Hellgren, 2002). The assumption that a low level of job insecurity could be harmful too, originates from the assumption that people need some pressure in order to feel (and perform) well. The hypothesis of curvilinear relationships with well-being has rarely been tested, because most scholars only analyse linear associations with stressors (e.g. Warr, 1987 and 1994). Warr limits his theory to mental health and affective well-being. His hypothesis can however be expanded to attitudes towards the organisation, in order to explore whether it is possible to generalise Warr's theory. This leads to the formulation of two additional hypotheses: a similar curvilinear association will be observed with lower organisational commitment and related attitudes (hypothesis $2 \mathrm{~b}$ ), and with the evaluation of management (hypothesis 2c).

\section{RESEARCH DESIGN}

Research approach

This study has a cross-sectional design, and makes use of previously collected data (secondary analysis of already existing data).

\section{Procedure and respondents}

769 employees of a European multinational company from the metalworking industry completed a written questionnaire, intended to assess the organisational climate. The employees originated from seven branches of this multinational company, spread across three countries, namely Belgium (2 branches; 27 and 335 respondents respectively), Spain (2 branches; 101 and 67 respondents respectively) and England (one branch; 139 respondents). Employees in Sales and Marketing (77 respondents) also participated, even though they were working in various European countries. 23 respondents failed to indicate their country or branch. All white-collar workers and managers were invited to participate in the research. A random sample of $20 \%$ of the blue-collar workers was selected. The survey was commissioned by the company and took place during working hours, which explains the high response rate $(93 \%$; varying between $65,5 \%$ (Sales and Marketing) and 100\%). A detailed interview procedure was developed in order to guarantee the confidentiality and anonymity of the results, so that respondents could freely express their views. The sample was heterogeneously composed according to occupational status: About one third $(36,4 \%)$ were blue-collar workers, $28,4 \%$ were white-collar workers and $35,2 \%$ were (junior or senior) management. About $20 \%$ of the sample was female and nearly all respondents $(96,5 \%)$ had a permanent employment contract. The age distribution was as follows: $7 \%$ were younger than 25 years old, $40,7 \%$ were between 25 and 34 years old, $28,6 \%$ between 35 and 44 years, $18,7 \%$ between 45 and 54 years, and $5 \%$ were 55 years old or older. Three more or less equal groups were observed regarding tenure: $33,5 \%$ worked no longer than 5 years in their company, $30,9 \%$ had a tenure between 6 and 15 years, and 35,6\% worked in their company for at least 16 years. Company management had no redundancy plans in the near future. The data collected thus concern a group of branches in which there were no 'objective' reasons for job insecurity at the time of the survey.

\section{Measurements}

First of all, the respondents had to evaluate the item "I am concerned about my long-term job security" on a 5-point scale (answering categories: 'totally agree', 'partly agree', 'partly agree, partly disagree' (neutral midpoint), 'partly disagree', 'totally disagree'.

Secondly, the respondents had to evaluate a large number of items regarding a large number of workplace topics, such as working conditions, colleagues, job content, supervision and the management of the company. The questionnaire was developed by scholars outside the company and is used by this multinational to periodically survey its organisational climate. In this article, only a specific selection of scales will be used, suited to test the hypotheses: Assessments of satisfaction, evaluations of the management and evaluations of the company as a whole (see hereafter). After performing a principal components analysis on every separate set of items (followed by separate analyses of reliability), items referring to the same construct were grouped in a scale. All scales vary between 0 (maximum disagreement with the scale content) and 10 (maximum agreement with the scale content), with 5 as the neutral mid-point. This resulted in 15 scales, which can be grouped into three categories. These three groups of scales will be discussed in a slightly different order than in the introduction of this article. Scales referring to the evaluation of management are listed in between job satisfaction and organisational attitudes, expressing their 'in between status' (see above).

Aspects of satisfaction were measured with four scales: job satisfaction (7 items; alpha $=0,89$ ), wage satisfaction (4 items; alpha $=0,83$ ) satisfaction with promotion prospects (8 items; alpha $=0,90)$ and satisfaction with colleagues (7 items; alpha $=$ $0,82)$.

Six scales related to the evaluation of management: a positive evaluation of the direct supervisor (14 items; alpha $=0,94$ ), a positive evaluation of the information given by management (5 items; alpha $=0,69$ ), the evaluation of management as stimulating ( 4 items; alpha $=0,83$ ), a positive evaluation of local management ( 7 items; alpha $=0,87$ ), a positive evaluation of international management (4 items; alpha = $0,84)$, and the evaluation of the existing performance appraisals as correct $(4$ items; alpha $=0,83)$. These scales partially overlap and probably cover the most important aspects of the evaluation of the management of this multinational organisation.

Five scales measure aspects of the attitude towards the company: 'the company listens to its employees' (5 items; alpha $=0,84$ ), 'the industrial relations did improve lately' (4 items; alpha = $0,79)$, commitment to the company ( 2 items; alpha $=0,78)$, pride in belonging to this multinational company (4 items; alpha = 0,85 ), and the desire to leave the company ( 2 items; alpha $=$ 0,70 ). The attitudes towards the company thus cover a broader range of organisational topics than the traditional concepts in job insecurity research, such as organisational commitment and turnover intentions.

\section{Statistical analysis}

The hypotheses are tested by univariate analysis of variance. The averages will be tested pair wise, using Tukey's Studentised Range (HSD)-contrasts. In testing hypothesis 2, the focus will be on the difference between the respondents scoring 'partly agree, partly disagree' (the neutral midpoint of the scale) and those scoring that they (totally or partly) agree or (totally or partly) disagree with the job insecurity item, since these differences indicate curvilinearity. 


\section{RESULTS}

Table 1 shows that $48,2 \%$ of the respondents were concerned about their long-term job security. About 20\% felt very insecure, and $28,2 \%$ reported to feel somewhat insecure. In addition to this, $29,1 \%$ were not sure, scoring between concerned and not concerned ('partly agree, partly disagree'. the neutral midpoint). About $22,7 \%$ of the respondents did not report worries about long-term employment. They are the 'job secure' respondents. Note that the group which stated that they are 'very secure' (total disagreement with the item) is rather small: only $5,5 \%$ (or 42 respondents). This means that some caution is needed when comparing this category with the other categories (each covering a larger number of respondents, between e.g. 132 and 223 persons).

TABLE 1

EVALUATION OF THE ITEM "I AM CONCERNED ABOUT MY LONG-TERM JOB INSECURITY" $(\mathbf{N}=769)$

\begin{tabular}{lc}
\hline & $\%$ \\
\hline Total agreement (very insecure) & 20,0 \\
Partial agreement (insecure) & 28,2 \\
Partial agreement, partial disagreement (in between) & 29,1 \\
Partial disagreement (secure) & 17,2 \\
Total disagreement (very secure) & 5,5 \\
Total group & 100,0 \\
\hline
\end{tabular}

Table 2 contains the results of the univariate analyses of variance in which the averages of the five groups in table 1 on all scales are compared and tested. These five groups are renamed in table 2 . Those in 'total disagreement' with the item in table 1 are labelled the 'very secure', and those in 'total agreement' the 'very insecure'. Those who stated that they 'partly disagreed' are labelled as the 'secure', and those who partly 'agreed' as the 'insecure'. The category stating 'partly agree, partly disagree' was labelled 'in between'. In discussing the results, the results regarding hypothesis 1 will be discussed first. All results regarding the test of hypothesis 2 will be discussed afterwards.

Regarding the satisfaction scales, a statistically significant association between long-term job insecurity and three of the four satisfaction scales is observed. The strongest differences occur with regard to job satisfaction and satisfaction with promotion prospects, with insecure respondents scoring lower on these attitudes, as expected. There is also a significant association with the scores on the scale 'wage satisfaction', with insecure respondents scoring lower than secure respondents too. Finally, it is interesting to note that there is no statistically significant difference between the five groups regarding satisfaction with their colleagues. Hypothesis $1 \mathrm{a}$ is for the greater part confirmed.

There are also significant associations between long-term job insecurity and four of the six scales measuring the evaluation of (departmental or company) management. Long-term insecurity is associated with a less favourable evaluation of the direct supervisor, the information provided by management, the stimulation offered by management, and a less positive evaluation of the correctness of the performance appraisals of the direct supervisor. Contrary to expectations, however, no statistically significant association with the evaluation of local and international management is observed. This means that hypothesis $1 \mathrm{c}$ is only partially confirmed.

Finally, there are also significant associations between longterm job insecurity and three out of five scales measuring organisational attitudes. Long-term insecurity is associated with a lower evaluation of the capacity of the company to listen to its employees, with the view that the industrial relations in the company did not improve lately, and with lower organisational commitment. Contrary to expectations,

TABle 2

DIFFERENCES BETWEEN THE FIVE (IN)SECURE GROUPS REGARDING STATISFACTION, EVALUATION OF MANAGEMENT AND ORGANISATIONAL ATTITUDES (ANALYSIS OF VARIANCE)

\begin{tabular}{|c|c|c|c|c|c|c|c|c|}
\hline \multicolumn{9}{|c|}{ Long-term job insecurity } \\
\hline Scales (1) & Very secure & Secure & In between & Insecure & $\begin{array}{c}\text { Very } \\
\text { insecure }\end{array}$ & F-value (2) & $\begin{array}{l}\text { Degrees of } \\
\text { freedom }\end{array}$ & P-value \\
\hline \multicolumn{9}{|l|}{ Satisfaction } \\
\hline Job satisfaction & $6,4^{\mathrm{a}, \mathrm{b}}$ & 7,3 a & $6,4 \mathrm{~b}$ & $6,5 \mathrm{~b}$ & $6,2 \mathrm{~b}$ & 6,08 & $(4,692)$ & 0,000 \\
\hline Wage satisfaction & 3,6 & 4,7 & 4,5 & 4,4 & 3,9 & 2,48 & $(4,548)$ & 0,036 \\
\hline Satisfaction with promotion prospects & $3,9 \mathrm{a}, \mathrm{c}$ & $5,2 \mathrm{~b}$ & $4,6^{a, b, c}$ & 4,7 a,b & $4,1^{c}$ & 7,15 & $(4,686)$ & 0,000 \\
\hline Satisfaction with colleagues & 6,1 & 6,7 & 6,6 & 6,5 & 6,7 & 0,88 & $(4,580)$ & 0,662 \\
\hline \multicolumn{9}{|l|}{ Evaluation of management } \\
\hline Positive evaluation of the direct supervisor & $5,4 \mathrm{a}, \mathrm{c}$ & $6,9 \mathrm{~b}$ & $6,1 \mathrm{a}, \mathrm{c}$ & $6,2 \mathrm{a}, \mathrm{c}$ & $6,2 \mathrm{a}, \mathrm{c}$ & 5,04 & $(4,695)$ & 0,000 \\
\hline Management gives good information & $5,8 \mathrm{a}, \mathrm{b}$ & 6,5 a & $6,0 \mathrm{a}, \mathrm{b}$ & $5,9 \mathrm{~b}$ & $5,7 \mathrm{~b}$ & 3,69 & $(4,640)$ & 0,008 \\
\hline Management is stimulating & $6,4 \mathrm{a}, \mathrm{b}$ & 7,0 a & $6,3 \mathrm{~b}$ & $6,4 \mathrm{a}, \mathrm{b}$ & $6,3 \mathrm{~b}$ & 2,43 & $(4,726)$ & 0,023 \\
\hline Positive evaluation of local management & 5,4 & 6,0 & 5,7 & 5,7 & 5,5 & 1,29 & $(4,625)$ & 0,698 \\
\hline Positive evaluation of international management & 6,1 & 6,5 & 5,9 & 6,0 & 6,2 & 1,20 & $(4,430)$ & 0,758 \\
\hline Performance appraisals are correct & $5,1 \mathrm{a}, \mathrm{b}$ & 5,9 a & $4,9 \mathrm{~b}$ & $5,0 \mathrm{~b}$ & $4,9 \mathrm{~b}$ & 4,28 & $(4,734)$ & 0,003 \\
\hline \multicolumn{9}{|l|}{ Organisational attitudes } \\
\hline The company listens to its employees & $5,9 \mathrm{a}, \mathrm{b}$ & $6,8^{\text {a }}$ & $6,3 \mathrm{a}, \mathrm{b}$ & $6,1 \mathrm{~b}$ & $5,8 \mathrm{~b}$ & 4,12 & $(4,730)$ & 0,004 \\
\hline Industrial relations have improved lately & 5,6 a,b & 6,0 a & 5,7 a & $5,3 \mathrm{a}, \mathrm{b}$ & $4,7 \mathrm{~b}$ & 3,64 & $(4,572)$ & 0,008 \\
\hline Commitment to the company & 4,9 & 5,6 & 5,3 & 4,9 & 4,9 & 2,50 & $(4,729)$ & 0,028 \\
\hline Pride in belonging to this multinational & 7,5 & 7,7 & 7,3 & 7,2 & 7,6 & 1,52 & $(4,651)$ & 0,852 \\
\hline Desire to leave the company & 7,9 & 7,3 & 7,5 & 7,5 & 7,7 & 0,70 & $(4,723)$ & 0,751 \\
\hline
\end{tabular}

(1) All scales are 10-point scales (' 0 '=maximum disagreement with the content of the scale; ' 10 '=maximum agreement with the content of the scale; ' 5 '=neutral mid-point).

(2) Means in the same row that do not share subscripts differ at $\mathrm{p}<.05$ in the Tukey honestly significant difference comparison. Means that share subscripts are not different from each other. 
no differences with regard to the desire to leave the company, and with pride in working for this multinational company are found. This means that also hypothesis $1 \mathrm{~b}$ is only partially confirmed.

We can conclude that the findings mostly (although not fully) confirm hypothesis 1 , as 10 out of 15 tests show the expected associations. Long-term job insecurity seems to be associated with lower satisfaction, a less favourable evaluation of management, and less positive attitudes towards the organisation. These findings, however, do not yet allow conclusions regarding hypothesis 2 . In order to test this hypothesis, the various scores of the five groups in table 1 are compared (pair wise test, using Tukey's Studentised Range (HSD)-contrasts). As stated before, the focus is on the differences between the respondents who place themselves into the 'neutral' middle category of the scale and those who (totally or partly) agree or (totally or partly) disagree with the job insecurity item, since these differences indicate curvilinearity.

Hypothesis 2 a relates to the satisfaction scales. The middle category does not differ significantly from the insecure or from the very insecure on any of the satisfaction scales. The comparison with the secure respondents shows that the middle category only once differs from the secure: the secure are more satisfied with their job in comparison to the middle category. These findings suggest little evidence in favour of hypothesis $2 \mathrm{a}$. Instead, two out of the three significant associations with the satisfaction scales produce a linear association, with the secure showing higher scores.

Hypothesis $2 \mathrm{~b}$ relates to the organisational attitudes. The results in table 2 do not corroborate the hypothesis of curvilinearity either. The middle category only differs from the very insecure regarding the evaluation of the industrial relations in the company, with a less positive score among the very insecure. No difference between the middle category and the secure categories is found. Instead, a linear trend is apparent, with secure respondents showing higher scores on most scales.

Hypothesis 2c relates to the evaluation of management. Here again, no differences are found between the middle category and those who feel insecure. Again, a clear linear trend seems apparent, with the secure expressing more positive evaluations than the middle category or the insecure.

In sum, the results do not corroborate hypothesis 2 , stating that long-term job insecurity will show a curvilinear association with satisfaction scores or with attitudes towards the organisation or management. Most reported associations show a linear trend, with secure respondents expressing higher satisfaction or more favourable organisational attitudes than the middle category or the insecure. It is striking that the middle category often does not differs in score compared to the insecure or the very insecure category. The finding that the insecure and the very insecure do not differ from each other (with the exception of satisfaction with promotion) is also striking. These findings will be discussed in the final part of this article.

Finally, the position of the (small) category of 'very secure' respondents is striking, because this (small) category seems to refute the idea of a linear association between long-term job insecurity and outcomes. This category practically always scores lower on the various scales than their secure counterparts. These differences, however, are only statistically significant on two occasions. In comparison to the secure, the very secure are significantly less satisfied with their promotion prospects and with their direct supervisor. For all other comparisons, no statistically significant differences are found.

\section{DISCUSSION}

In this article, two unresolved issues in job insecurity research were addressed. First of all, the hypothesis is tested that long-term job insecurity, a neglected issue in job insecurity research, is associated with lower job satisfaction, a less positive evaluation of management and less positive organisational attitudes. Next, a hypothesis was derived from the Vitamin-model of Peter Warr (1987 and 1994), in an attempt to broaden and enrich actual job insecurity research with the test of contemporary theory in work psychology. The hypothesis stated that (long-term) job insecurity will show a curvilinear association with various outcome variables, such as job satisfaction and organisational attitudes. Secondary data, collected for 769 employees of a multinational company in the industrial sector, were used to test both hypotheses.

\section{Conclusions and interpretation}

The results corroborated the first hypothesis to a large extent. Ten out of 15 scales, used to test the association with longterm job insecurity, showed the expected relationships. Insecure workers were less satisfied regarding their job, wage and promotion prospects, evaluated their management less favourable, were less committed to their company, and were less positive regarding a variety of company policies and practices (e.g. provision of information, application of performance appraisals, the capacity of the organisation to listen to its employees, and industrial relations). These findings are in line with the job insecurity literature, which documents the negative consequences of job insecurity for job and organisational attitudes (e.g. Greenhalgh \& Rosenblatt, 1984; Sverke \& Hellgren, 2002; Sverke et al., 2004). These results, however, also extend the results of previous research, because they show that the detrimental consequences of job insecurity can also be observed when one focuses on longterm job insecurity, an aspect that has been neglected in previous research.

It is interesting to note that not all scales, used to test hypothesis 1 , showed the expected association with long-term job insecurity. No significant association was found between job insecurity and satisfaction with colleagues. Such an association would perhaps be implausible, however, unless colleagues were to be held responsible for the experienced job insecurity. This lack of a significant association could suggest that dissatisfaction because of job insecurity is not a generalised phenomenon. Rather, it seems to be limited to specific work related areas that are relevant to job insecurity (e.g. organisational commitment and the evaluation of management). The absence of a significant association with the evaluation of local and international management is striking, and contrary to expectations. This finding could be caused by the focus on long-term job insecurity. It is possible that employees do not hold their company (e.g. local or international management) responsible for long-term job insecurity, since this phenomenon is caused by global evolutions in the international economy. Finally, and equally contrary to expectations, no association with turnover intentions was observed. Neither did the pride in working for this multinational company differ between the secure and the insecure. Both findings could also be due to the focus on longterm job insecurity. When one experiences insecurity in the long run, because of global evolutions in the economy, moving to another company might not be evaluated as a good coping strategy, because this new company will not be able to protect the job either.

The second hypothesis, derived from Warr's vitamin-model (Warr, 1987 and 1994) is not supported in this study. Most associations between outcome variables and long-term job insecurity are linear rather than curvilinear. The secure respondents exhibit positive scores, and the insecure 
respondents score less favourably. Warr's assumption that 'too much security' could be as harmful as 'too little security' has thus been refuted. This finding adds to previous research in at least two ways. First, it shows that it can be useful to introduce work psychological theory into the job insecurity domain, in order to clarify its meaning and consequences. Next, it extends previous research, because Warr's vitamin-model has rarely been tested in empirical research.

The test of hypothesis 2 revealed three additional findings, which need to be discussed. First, no significant differences are found between the two 'insecure' categories (the 'insecure' and the 'very insecure' respondents), with the sole exception of satisfaction with promotion prospects. This suggests that insecurity as such appears to be problematic, irrespective of its intensity. The next finding adds to this conclusion. It was striking that the middle category, who expressed an 'in between' attitude (in between concerned and not concerned), did not differ much from the two insecure categories. This 'neutral' category showed the same unfavourable attitudes as those who felt insecure. These findings are not uncommon in the literature (see e.g. De Witte, 1999), and suggest that 'not feeling secure' is stressful, regardless whether one feels 'in between', 'rather insecure' or 'very insecure'. This is clearly illustrated by the scores of the 'secure' respondents, who differed markedly from the three latter categories.

Finally, it is worthwhile to note that the (small) category of 'very secure' respondents often showed a more negative attitude than the category of 'secure' respondents. This difference within the secure category is noticeable, since it does indicate a trend towards a curvilinear relationship between job insecurity and various outcome variables. Some caution in interpretation is warranted here, however, as the differences between the very secure and the secure were only statistically significant on two occasions. In comparison to the secure, the very secure are significantly less satisfied with their promotion prospects and with their direct supervisor. For all other comparisons, no significant differences are found. Perhaps it is not so much job security that is a problem for this category, but rather their blocked promotion prospects in the near future. Maybe these employees have the feeling that their direct supervisor is obstructing their promotion prospects. As a consequence, their evaluation of their direct supervisor is rather negative. Given the limited size of this divergent group, further research is needed to find out whether these findings can be replicated.

Limitations of this study and suggestions for future research Further research is not only needed in order to replicate the main findings, but is also needed to overcome some limitations of this study. The study was limited to various branches of just one large multinational company. In consequence, a larger and more heterogeneous sample is needed in future research. The study had a cross-sectional design, so no causal conclusions can be drawn from its results. Longitudinal research is needed to test the consequences of long-term job insecurity. In this study, no original data were used. Instead, a secondary analysis was performed on already collected data. This strategy has evident advantages, as it allows testing hypotheses with available data, avoiding the costs of data collection. One obvious disadvantage, however, is the limited availability of measures. The data are all self-reported data, which might induce some auto-correlation with reported job satisfaction and other outcome variables. Next to this, one could criticize the use of just one item in order to measure the independent variable: long-term job insecurity (e.g. Sverke \& Hellgren, 2002). Research shows that the use of just one item risks reducing the reliability of the measurement (e.g. Sverke et al., 2002). Here again, this limitation, due to the use of secondary data, needs to be overcome in future research. It seems worthwhile to develop a variety of items on the perception of long-term job insecurity, in order to develop a reliable scale. Note that meta-analytic research leads to the conclusion that the use of single items underestimates the associations between job insecurity and outcome variables. As a consequence, the association of long-term job insecurity and outcome variables could be stronger than those reported in this article. Finally, only an item regarding long-term insecurity could be used in this study, as no items measuring short-term insecurity were available. This limits the conclusions, because the effects of both kinds of insecurity could not be compared. Future research should try to analyse the differential effects of short versus long-term job insecurity.

\section{Importance for practice and recommendations}

The core issue of this study relates to long-term job insecurity. Two findings of this study highlight the importance of this kind of job insecurity for practice. The findings first of all suggest that a large amount of the workforce experiences longterm job insecurity. In this study, no less than $48 \%$ of the respondents reported worries regarding their long-term job security. This percentage is similar to the percentage reported by other scholars (e.g. Roskies \& Louis-Guerin, 1990), and clearly exceeds the percentage of those expressing short-term job insecurity, as reported in the literature (see e.g. De Witte, 1999; Roskies \& Louis-Guerin, 1990). Secondly, the findings of this study suggest that long-term job insecurity is also detrimental to job satisfaction and to the evaluation of the organisation. Taken together, both conclusions suggest that long-term job insecurity is a much more important phenomenon than short-term job insecurity, since it affects more workers and seems equally detrimental for work and organisation related attitudes. As a consequence, it seems important to develop specific policies in order to tackle this problem. First of all, companies should be aware of the importance of this topic, and should develop sensitivity for this subject. This includes screening their workforce regarding signs of insecurity, because these perceptions might hamper employee and organisational functioning. Next, specific practices devised to reduce job insecurity and its harmful effects, should be developed and implemented. These practices have been described elsewhere (see e.g. Sverke \& Hellgren, 2002; Sverke et al., 2004). Examples are practices to increase communication and to reduce feelings of organisational injustice, and policies to enhance participation in decision making.

\section{REFERENCES}

Ashford, S., Lee, C. \& Bobko, P. (1989). Content, causes, and consequences of job insecurity : A theory-based measure and substantive test. Academy of Management Journal, 32, 803-829.

Barling, J. \& Kelloway, K. (1996). Job insecurity and health: The moderating role of workplace control. Stress Medicine, 12 253-259.

Borg, I. \& Elizur, D. (1992). Job insecurity: Correlates, moderators and measurement. International Journal of Manpower, 13, 13-26.

Burchell, B. (1994). The effects of labour market position, job insecurity and unemployment on psychological health. In D. Gallie, C. Marsh \& C. Vogler (Eds.). Social Change and the Experience of Unemployment. (pp. 188-212), Oxford : University Press.

Davy, J. A., Kinicki, A. J., \& Scheck, C.L. (1997). A test of job insecurity's direct and mediated effects on withdrawal cognitions. Journal of Organisational Behavior, 18, 323-349.

Dekker, S. \& Schaufeli, W. (1995). The effects of job insecurity on psychological health and withdrawal: A longitudinal study. Australian Psychologist, 30, 57-63.

De Witte, H. (1999). Job Insecurity and Psychological Wellbeing: Review of the Literature and Exploration of some Unresolved Issues. European Journal of Work and Organisational Psychology, 8, 155-177. 
De Witte, H. (2005), Does job insecurity affect the organisation as well? Minutes of 'The changing world of work' Conference, Potchefstroom, 8 \& 9 March 2005. (pp. 144-146), North-West University, Vaal Triangle Campus, South-Africa.

Greenhalgh, L. \& Rosenblatt, Z. (1984). Job insecurity : Toward conceptual clarity. Academy of Management Review, 9, 438448.

Hartley, J., Jacobson, D., Klandermans, B. \& Van Vuuren, T. (1991). Job insecurity. Coping with jobs at risk. London : Sage Publications.

Heaney, C., Israel, B. \& House, J. (1994). Chronic job insecurity among automobile workers : Effects on job satisfaction and health. Social Science Medicine, 38, 1431-1437.

Hellgren, J., Sverke, M., \& Isaksson, K. (1999). A twodimensional approach to job insecurity: Consequences for employee attitudes and well-being. European Journal of Work and Organisational Psychology, 8, 179-195.

Hitt, M., Keats, B., Harback, H. \& Nixon, R. (1994). Rightsizingbuilding and maintaining strategic leadership: A longterm competitiveness. Organisational Dynamics, 23, 18-32.

Iversen, L. \& Sabroe, S. (1988). Psychological well-being among unemployed and employed people after a company closedown : A longitudinal study. Journal of Social Issues, 44, 141-152.

Kinnunen, U., Mauno, S., Nätti, J., \& Happonen, M. (2000). Organisational antecedents and outcomes of job insecurity: A longitudinal study in three organisations in Finland. Journal of Organisational Behavior, 21, 443-459.

Klandermans, B. \& van Vuuren, T. (1999). Job insecurity. European Journal of Work and Organisational Psychology, 8, 145-314.

Kozlowski, S., Chao, G., Smith, E., \& Hedlung, J. (1993). Organisational downsizing: Strategies, interventions and research implications. International Review of Industrial and Organisational Psychology, 8, 263-332.

Landsbergis, P. (1988). Occupational stress among health care workers: A test of the job demands-control model. Journal of Occupational Behaviour, 9, 217-239.

Lim, V. (1996). Job insecurity and its outcomes: Moderating effects of work-based and non-work-based social support. Human Relations, 49, 171-93.

Lord, A. \& Hartley, J. (1998). Organisational commitment and job insecurity in a changing public service organisation. European Journal of Work and Organisational Psychology, 7, 341-354.

Mak, A. \& Mueller, J. (2000). Job insecurity, coping resources and personality dispositions in occupational strain. Work \& Stress, 14, 312-328.
Mohr, G. (2000). The changing significance of different stressors after the announcement of bankruptcy: A longitudinal investigation with special emphasis on job insecurity. Journal of Organisational Behavior, 21, 337-359.

Nolan, J., Wichert, I. \& Burchell, B. (2000). Job insecurity, psychological well-being and family life. In E. Heery, \& J. Salmon (Eds.). The insecure workforce. (pp. 181-209), London: Routledge.

OECD (1997). Is job insecurity on the increase in OECD countries? OECD Employment Outlook, July, 129-159.

Orpen, C. (1993). Correlations between job insecurity and psychological well-being among white and black employees in South Africa. Perceptual and Motor Skills, 76, 885-886.

Probst, T. \& Brubaker, T. (2001). The effects of job insecurity on employee safety outcomes: Cross-sectional and longitudinal explorations. Journal of Occupational Health Psychology, 6, 139-158.

Purcell, K. \& Purcell, J. (1998). In-sourcing, out-sourcing, and the growth of contingent labour as evidence of flexible employment strategies. European Journal of Work and Organisational Psychology, 7, 39-59.

Roskies, E. \& Louis-Guerin, C. (1990). Job insecurity in managers: Antecedents and consequences. Journal of Organisational Behaviour, 11, 345-359.

Roskies, E., Louis-Guerin, C. \& Fournier, C. (1993). Coping with job insecurity: How does personality make a difference? Journal of Organisational Behavior, 14, 617-630.

Sverke, M. \& Hellgren, J. (2002). The nature of job insecurity: Understanding employment uncertainty on the brink of a new millennium. Applied Psychology: An International Review, 51, 23-42.

Sverke, M., Hellgren, J. \& Näswall, K. (2002). No security: A meta-analysis and review of job insecurity and its consequences. Journal of Occupational Health Psychology, 7, 242-264.

Sverke, M., Hellgren, J., Näswall, K., Chirumbolo, A., De Witte, H. \& Goslinga, S. (2004). Job Insecurity and Union Membership. European Unions in the Wake of Flexible Production. Brussels: P.I.E.-Peter Lang.

Van Vuuren, T. (1990). Met ontslag bedreigd. Werknemers in onzekerheid over hun arbeidsplaats bij veranderingen in de organisatie. Amsterdam : VU Uitgeverij.

Van Vuuren T., Klandermans B., Jacobson D. \& Hartley J. (1991). Employees' reactions to job insecurity. In J. Hartley et al. Job Insecurity. Coping with Jobs at Risk. (pp. 79-103), London: Sage.

Warr, P. (1987). Work, Unemployment and Mental Health. Oxford: Clarendon Press.

Warr, P. (1994). A conceptual framework for the study of work and mental health. Work \& Stress, 8, 84-97. 